\title{
Effect of Different Nitrogen Rate and Barley (Hordeum vulgare L.) Variety to different Growth Analysis at Hawassa, Southern Ethiopia
}

\author{
Demis Fikre Limeneh* \\ Ethiopian Institute of Agricultural Research, Kulumsa Research Center, \\ Assela, Ethiopia; P.O. Box -489
}

\begin{abstract}
Nitrogen $(\mathrm{N})$ is the most common limiting nutrient in agricultural systems throughout the world. Crops need sufficient available $\mathrm{N}$ to achieve optimum yields and adequate grain-protein content. Consequently, sub-optimal rates of $\mathrm{N}$ fertilizers typically cause lower economic benefits for farmers. On the other hand, excessive $\mathrm{N}$ fertilizer use may result in environmental problems such as nitrate contamination of groundwater and emission of $\mathrm{N}_{2} \mathrm{O}$ and NO. In spite of the economical environmental importance of good $\mathrm{N}$ fertilizer management, the development of an optimum fertilizer recommendation is still a major challenge in most agricultural systems. Nitrogen supplies have a strong influence on the physiological and phonological characteristics of crop as well as on the quality of barley growth, which have the capacity to enhanced yield and production of barley. In order to evaluate the physiological and quality assessment of barley in response to soil fertilization of nitrogen a field trail was carried out having randomized complete block design with four replications and three different treatments of nitrogen allotted to plots at planting and tillering growth stages. Results indicated that maximum leaf area ratio, maximum crop growth rate and maximum dry weight was recorded when the crop was none fertilized with as compared to fertilized nitrogen. Likewise maximum leaf area index was obtained with the non-fertilization of nitrogen. Control practice resulted in high values for all recorded parameters. Thus it is possible to obtain maximum physiological traits as well as vigorous barley through non nitrogen application.
\end{abstract}

Keywords: Barley, leaf area index, leaf area ratio, crop growth rate, Biomass and nitrogen.

DOI: $10.7176 /$ ALST/86-01

Publication date:March $31^{\text {st }} 2021$

\section{Introduction}

Nutrients play a significant role in improving productivity and quality of crops. Therefore, increasing the productivity of barley with a good quality is an important target for producers. Nitrogen fertilizer is considered a key input affecting crop production and might be as crucial as water to growth and nutrient uptake (Jaradat and Haddad, 1994). Nitrogen being the most often growth limiting nutrient is found to be an essential constituent of metabolically active compounds such as amino acids, proteins, co-enzymes and some non-pertinacious ones(Biwas and Mukherjee, 1993). Nitrogen comprises $7 \%$ of total dry matter of plants and is a constituent of many fundamental cell components (Bungard et. al., 1999). Nitrogen constitutes about 5 to $6 \%$ of soil organic matter by weight and it is added to the soil both in symbiotic and non-symbiotic forms from the atmosphere. Hence, it plays a vital role in all living tissues of the plant. No other element has such an effect on promoting vigorous plant growth as has $\mathrm{N}$. Abundant protein tends to increase the size of the leaves, and accordingly, brings about an increase in carbohydrate synthesis (Panhwar, 2004). Plant roots take up nitrogen from the soil solution principally as nitrates $\mathrm{NO}_{3}{ }^{-}$and $\mathrm{NH}_{4}+$ ions. Although certain plants grow best when provided mainly one or the other forms, a relatively equal mixture of the two ions gives the best results with most plants. Nitrate is the preferred form of $\mathrm{N}$ for uptake by most plants, and it usually is the most abundant form that can be taken up in well-aerated soils. The quantities of $\mathrm{NO}_{3}{ }^{-}$found in soil at any time, however, usually represent only enough $\mathrm{N}$ to support uptake for a short period. Nitrate anions move easily to the root with the flow of soil water and exchange at the root surface with $\mathrm{HCO}_{3}{ }^{-}$or $\mathrm{OH}^{-}$ions that, in turn, stimulate an increase in the $\mathrm{pH}$ of the soil solution immediately around the root. In contrast, ammonium cations exchange at the root surface with hydrogen ions, thereby lowering the $\mathrm{pH}$ of the solution around the roots (Brady and Weil, 2002). Onion also takes up nitrates in much greater amount than ammonium (Bosch and Currah, 2002).

Plant tissues usually contain more $\mathrm{N}$ than any other nutrient normally applied as a fertilizer. Nitrogen is an integral component of many essential plant compounds. This nitrogen is needed to form chlorophyll, proteins and it is a major part of all amino acids and many other molecules essential for plant growth and other critical nitrogenous plant components such as the nucleic acids and chlorophyll (Brady and Weil, 2002). Nitrogen in the plant controls the utilization of phosphorus and potassium and excess could delay maturity by causing too much vegetative growth (Gustfson, 2010).

Inadequate $\mathrm{N}$ inputs can reduce grain yield and quality below acceptable level sowing to lodging and disease (O'Donovan et al., 2015; Ding et al., 2015), while excessive $\mathrm{N}$ inputs usually produce undesirable high protein 
levels (O'Donovan et al., 2015)

An adequate application of nitrogen fertilizer can enable the plant to establish canopy in short time which can significantly contribute in light interception, photosynthesis and grain filling (Al Barrak, 2006; Ding et al., 2015). As far as plant productivity in arid regions is far below than the potential yield due to many factors of which planting date being the most important factor affecting the productivity (Faki et al., 1990; Zia et al., 2014). Optimum fertilizer application and cultivation of suitable varieties with appropriate agronomic practices in specific environment are necessary for obtaining good yields (Rizk et al., 2012).

Balanced nutrition is an essential component of nutrient management and plays a significant role in increasing crop production and its quality. For the major processes of plant development and yield formation the presence of nutrients like N, P, K, S and Mg etc in balance form are essential (Randhawa and Arora, 2000). Nitrogen rate, type of nitrogen and timing of its application are important factors to increase barley yield and improve its flour quality (Garrido-Lestache et al., 2005). Crop biomass and crop growth rate (CGR) are dependent on the ability of the canopy to intercept incoming photo- synthetically active radiations (IPAR), which is the function of leaf area index (LAI), leaf area and canopy architecture and then convert these radiation into new biomass. Nitrogen availability influences the efficiency of assimilated mobilization to sink during leaf senescence and thus affects leaf viability and activity (Wagan, 2003). Research also reported that radiation use efficiency might increase when nitrogen and sulfur supply rise, but in lower magnitude with respect to LAI and LAD (Fernado et al., 2008). LAI was reduced in crops grown under nitrogen deficiency (Caviglia and Sardas, 2001).

Light directly influences plant growth and flowering by inducing photosynthesis and feeding plants energy. Plants are dependent on light to generate food, induce the growing cycle and allow for healthy development. Moreover, to sustain higher photosynthetic capacity or survival, plants modify their morphology and biomass allocation at different light conditions (Feng et al., 2004). In the present study, light intensity strongly affected the biomass, biomass allocation, and morphological characters of different plants. The main objective of this study is to evaluate the growth of Barley (Hordeum vulgare L.) under different nitrogen fertilizer rates by using the growth analysis such as total dry matter, leaf area ratio (LAR), leaf area index (LAI) and crop growth rate (CGR).

\section{Materials and Methodology}

\subsection{Study Area}

The field experiment was conducted at the compound of Hawassa University in the College of Agriculture, Hwassa. The site is located $6.7^{\circ} \mathrm{N}$ and $38^{\circ} 29^{\prime} \mathrm{E}$ of latitude at an altitude of 1650 m.a.s.l with the mean annual rainfall of $900 \mathrm{~mm}$. The mean annual temperature maximum and minimum is $27^{\circ} \mathrm{C}$ and $13^{\circ} \mathrm{C}$ respectively. The soil of the experimental site is sandy loam with $\mathrm{pH}$ of 5.5. The research was done under irrigation, but some supplemented with autumn rain. The site is not this much suitable for barley production. The lab experiment was conducted at the department of Plant and Horticultural Sciences in the Physiology laboratory.

\subsection{Materials}

One barley variety (Holker) was taken from Department of plant science and Horticulture and sown at $100 \mathrm{~kg} / \mathrm{ha}$ seed rate $(60 \mathrm{gm} / \mathrm{plot}), \mathrm{N}_{0}, \mathrm{~N}_{23}, \& \mathrm{~N}_{46} \mathrm{~kg} /$ ha fertilizer levels $(0,30, \& 60 \mathrm{gm} / \mathrm{plot})$ applied in split at planting and during tillering stage, and100 $\mathrm{kg}$ DAP per hectare (60 gm TSP/plot) applied at planting were used in four replications.

\subsection{Experimental Design}

The experimental setup was a randomized complete block design (RCBD) with four replications and in each replication we have three treatments $\left(\mathrm{N}_{0}, \mathrm{~N}_{30}\right.$ and $\mathrm{N}_{60} \mathrm{gm} /$ plot). The barley was planted on $2 \mathrm{~m}$ by $3 \mathrm{~m}$ plot size for each treatment and fertilizer was applied at a rate of indicated above. Each plot contains ten rows which was $20 \mathrm{~cm}$ spaced from each other and barley seeds simply drilled in rows at planting on 9/11/2016 G.C. Plots were irrigated daily until the seed emerged and after the plants well established irrigated as necessary (of course supplemented with autumn rain some of the time).

\subsection{Method of data collection}

Destructive sampling on each plot from rows which were representatives for the whole plot from the mid vegetative growth phase was under taken. On 8/12/2016 G.C first sample was taken from the middle four rows $(20 \mathrm{~cm} \times 40$ $\mathrm{cm}$ ) from each plot. The leaf area (assimilatory area) was measured by using leaf area meter; the average leaf area of the whole sample plants was taken for statistical analysis. Finally for 48 hours we put in oven $\left(70^{\circ} \mathrm{c}\right)$ for measuring the dry weight. After two weeks on 21/12/2016 we took the second sample for each growth analysis on the same as above. On January 24, 2017 final data was taken for determining the dry weight of the whole plants (stem, leaf, tiller,) on two whole row per plot was harvested and chopped into pieces for the convenience of drying it in the sun and weight. 


\subsection{Growth analysis}

Growth analysis can be used to account for growth in terms that have functional or structural significance. The type of growth analysis requires measurement of plant biomass and assimilatory area (leaf area) and methods of computing certain parameters that describe growth.

\section{i. Leaf Area}

This is the area of photosynthetic surface produced by the individual plant over a period of interval of time and expressed in $\mathrm{cm}^{2}$ plant ${ }^{-1}$

\section{ii. Leaf Area Index (LAI)}

Leaf Area Index (LAI) is the ratio of the leaf of the crop to the ground area over a period of interval of time. The value of LAI should be optimum at the maximum ground cover area at which crop canopy receives maximum solar radiation and hence, the TDMA will be high.

$L A I=\frac{\text { Total leaf of a plant }}{\text { Ground area occupied by the plant }}$

\section{iii. Leaf Area Ratio (LAR)}

The term, Leaf Area Ratio (LAR) expresses the ratio between the area of leaf lamina to the total plant biomass or the LAR reflects the leafiness of a plant or amount of leaf area formed per unit of biomass and expressed in $\mathrm{cm}^{-2}$ $\mathrm{g}^{-1}$ of plant dry weight.

$L A R=\frac{\text { leaf area per plant }}{\text { Plant dry weight }}$

\section{iv. Relative Growth Rate (RGR)}

Relative Growth Rate (RGR) expresses the total plant dry weight increase in a time interval in relation to the initial weight or Dry matter increment per unit biomass per unit time or grams of dry weight increase per gram of dry weight and expressed as unit dry weight / unit dry weight / unit time $\left(\mathrm{g} \mathrm{g}^{-1}\right.$ day $\left.^{-1}\right)$.

$R C R=\frac{\text { Loge } \mathrm{W} 2-\text { Loge } \mathrm{W} 1}{\mathrm{t} 2-\mathrm{t} 1}$

Where, $\mathrm{W}_{1}$ and $\mathrm{W}_{2}$ are whole plant dry weight at $\mathrm{t}_{1}$ and $\mathrm{t}_{2}$ respectively

$\mathrm{t}_{1}$ and $\mathrm{t}_{2}$ are time interval in days

\section{Crop Growth Rate (CGR)}

The CGR explains the dry matter accumulated per unit land area per unit time $\left(\mathrm{g} \mathrm{m}^{-2} \mathrm{day}^{-1}\right)$

$\mathrm{CGR}=\frac{\mathrm{W} 2-\mathrm{W} 1}{\rho(\mathrm{t} 2-\mathrm{t} 1)}$

Where, $\mathrm{W} 1$ and $\mathrm{W} 2$ are whole plant dry weight at time $\mathrm{t} 1-\mathrm{t} 2$ respectively

$\rho$ is the ground area on which $\mathrm{W} 1$ and $\mathrm{W} 2$ are recorded.

CGR of a species are usually closely related to interception of solar radiation.

\section{Vi. Total dry matter production (TDMP) and its distribution}

The total dry matter production is the biomass accumulated by the whole plant over a period of interval of time and its distribution (allocation) to different parts of the plant such as roots, stems, leaves and the economic parts which controls the sink potential.

\subsection{Data Analysis}

Mean values for each growth analysis, parameters were taken and computed and subjected to analysis of variance (ANOVA) using Proc GLM procedures of SAS (9.1) program package. Test for statistical significance was calculated at $5 \%$ probability level using the $\mathrm{F}$ test. The F-test is not significantly different within treatments mean separation was not done (Steel and Torrie 1997).

\section{Result and Discussion}

\subsection{Growth parameters}

Table 1.The results from the parameters and primary values used for barley growth analysis (Leaf area index (LAI), Leaf area ratio (LAR), Crop growth rate (CGR) AND TOTAL BIOMASS)

\begin{tabular}{|c|c|c|c|c|c|c|}
\hline \multirow{2}{*}{$\begin{array}{l}\text { Nitrogen } \\
\text { (kg) }\end{array}$} & \multicolumn{2}{|r|}{ LAI } & \multicolumn{2}{|c|}{$\operatorname{LAR}\left(\mathrm{cm}^{2} \mathrm{gm}^{-1}\right)$} & \multirow[t]{2}{*}{ CGR $\left(\right.$ gmm $^{-2}$ day $\left.^{-1}\right)$} & \multirow[t]{2}{*}{$\mathrm{TBM}\left(\mathbf{g m ~ \mathbf { ~ m } ^ { - 2 } )}\right.$} \\
\hline & $\mathrm{LAI}_{1}$ & $\mathrm{LAI}_{2}$ & $\mathrm{LAR}_{1}$ & $\mathrm{LAR}_{2}$ & & \\
\hline 0 & $23.77 \pm \mathbf{2 . 1 7}$ & $76.81 \pm 7.45$ & $225.13 \pm 41.03$ & $220.9 \pm \mathbf{1 7 . 2 3}$ & $186.3 \pm \mathbf{3 0 . 0 7}$ & $656.25 \pm 24.8$ \\
\hline 23 & $24.04 \pm 3.23$ & $57.31 \pm 7.71$ & $226.77 \pm 46.9$ & $186.28 \pm 8.65$ & $155.35 \pm 46.35$ & $619.79 \pm 45.8$ \\
\hline 46 & $23.05 \pm 3.36$ & $61.26 \pm 7.56$ & $212.64 \pm 16.64$ & $186.28 \pm \mathbf{1 2 . 9 8}$ & $145.43 \pm 24.07$ & $645.83 \pm 64.77$ \\
\hline
\end{tabular}

The subscript " 11 " and " 2 "' for LAI and LAR in the above table show the first and the second taken samples.

For the leaf area index as well as for leaf area ratio, the first and the second samples were taken at 23 and 36 days after emergence respectively. On the other hand, the final harvest biomass samples were taken at 69 days after emergence. 
From the above experimental result the plots grown with N0 fertilizer level have greater LAI and CGR per plot and plots grown with $\mathrm{N} 23$ and N46 kg/ha have small LAI and CGR per plot as compared to both $\mathrm{N}_{0}$ fertilizer rates. Both leaf area index and crop growth rate have not positively correlation with nitrogen fertilizer nutrients due to the experimental site area of soil analysis is not tested, environmental factors ,over flooding or leaching problems, volatilization, irrigation problems, previous crop history and design problems etc but this result disagrees with the analysis of the growth supported by (Salvagiotti and Miralles, 2008) who stated that increase in nitrogen levels can results increased in LAI by as much as $62 \%$. This result much with laboratory conditions, most $\mathrm{C}_{3}$ plants grow 30 to $60 \%$ faster when $\mathrm{co}_{2}$ concentration is doubled (to $600-700 \mathrm{ppm}$ ), and the growth rate changes depend on nutrient status (Bowes, 1993)

The positive effect of nitrogen on the growth of stem and leaf area, which was reflected into taller plants thus higher green area for light interception and photosynthesis that leads to higher photo assimilates translocation and accumulated resulting in higher grain yield (Javaheri et al., 2014).The data regarding of leaf area indicate that different fertilizers treatments combinations have not significant relationship with leaf area (Table 1). Maximum leaf area was obtained from plots not treated with soil applied N0 soil, whereas minimum leaf area was obtained from $\mathrm{N} 23$ and $\mathrm{N} 46 \mathrm{~kg} /$ ha plots.

Also from the above experimental table result also shows that the level of nitrogen not increases both leaf area ratio (LAR) and biomass increases in the first and the second sample only in $\mathrm{N}_{0}$. This result disagrees with the analysis of the growth dynamics of barley variety at various nitrogen fertilizer levels. Research on barley in Virginia has shown that the end of tillering is the latest growth stage at which the crop can efficiently respond to $\mathrm{N}$ fertilizer application the maximum rate of crop dry-matter production. Tiller count and/or dry-matter production help to determine expected grain yields and, consequently, the crop's N requirement. (BAETHGEN W.E., ALLEY. (1989) and Greenwood (1982) observed in 22 barley species growing when nitrogen was optimal there was a common relation between the nitrogen concentration and the increasing dry weight of whole plant.

\subsection{Analysis of Variance}

From the experimental studies taken the analysis of variance shows not significant differences among the different nitrogen levels (treatments) for the dry weight (table 2). Plants grown under $\mathrm{N}_{0}$ fertilizer have higher dry weight than plants grown under $\mathrm{N} 23$ and $\mathrm{N}_{46} \mathrm{~kg} /$ ha fertilizer levels. This means that a plot grown without nitrogen fertilizer accumulates high dry matter than plants grown with ample nitrogen fertilizer levels. But our results disagree with added $\mathrm{N}$ induced more vegetative growth barley which resulted in big biomass and nitrogen fertilizer rate influence barley growth, yield and yield components (Donovan et al., 2015; Ding et al., 2015). For plant height the effect of nitrogen fertilizer was high. Our result was also contrast with Sinclair and Muchow (1995) findings and Added nitrogen supply increases the number of tiller buds and apical primordial that survive and also the size of individual leaves (Hay and Walker, 1989).

The problem of the result contrasts improper design, irrigation problems, soil fertility, previous cropping history, leaching of nitrogen, flooding problems happened one day and degree of freedom also lowers or it not recommended below 10 for field experiment because increasing error degree of freedoms for this reason our result became non significantly different from between treatments.

Table.2 Analysis of Variance in RCBD for the Final Harvest (dry matter above ground Biomass)

\begin{tabular}{|l|l|l|l|l|l|}
\hline Source of variation & DF & Sum of Squares & Mean Squares & F-Value & P-Value \\
\hline Replication & 3 & 15154.57 & 5051.52 & & \\
\hline Treatments & 2 & 2821.00 & $1410.50^{\text {ns }}$ & 0.13 & 0.88 \\
\hline Error & 6 & 67200.84 & 11200.14 & & \\
\hline Total & 11 & 85176.42 & & & \\
\hline
\end{tabular}

Ns $=$ means non-significant at $(\mathrm{p}<0.05)$

Coefficient of variance $(\mathrm{CV})=16.5 \%$

\section{Conclusion}

From this study we can conclude that barley dry matter production not significantly different from within treatments nitrogen fertilizer. Those plots grown with nitrogen fertilizer have produced less (lower) LAI, LAR, CGR and dry matter (biomass) production, but the plots grown without nitrogen fertilizer were produce in the reverse way.

\section{Recommendations}

Future recommendations will likely be based on a combination of current approaches (soil and plant indices, yield expectation, etc.) and information from nitrogen fertilizer. It is, therefore, crucial to continue or repeating research to improve indicators of $\mathrm{N}$ availability and to refine $\mathrm{N}$-level availability, including the use that can accurately trace the fate of $\mathrm{N}$ applied as synthetic fertilizers and to recommend best nitrogen level for the end users or the farmers. 


\section{References}

Al- Barrak KM. 2006. Irrigation interval and nitrogen level effects on growth and yield of canola (Brassica napus L.), Scientific Journal of King Faisal University (Basic and Applied Sciences) 7: 87-103.

BAETHGEN, W.E., ALLEY. M.M., Optimizing soil and fertilizer nitrogen use for intensively managed winter wheat II. Critical levels and optimum N fertilizer fates, Agron. J. 81 (1989) 120-125.

Biwas T.D. \& Mukherjee S.K. 1993. Text book of soil science ( $5^{\text {th }}$ ed.) Tata Mc Graw Hill, New Delhi. Pp.170197.

Bosch Sera A. D. \& Currah L. 2002. Agronomy of onions pp. 187-232. In: H.D. Rabinowich and Currah, L. (eds.), Allium crop Science: Recent advances. CABI Publishing, London

Bowes, G. (1993). Facing the inevitable:Plants and increasing atmospheric CO2. Annu. Rev. Plant Physiol. Plant Mol. Biol. 44: 309-332.

Brady N.C. \& Weil R.R. 2002. The nature and properties of soils. Thirteenth edition. Pearson Education Asia. Delhi, India. 960p.

Bungard R.A., Wingler A., Morton J.D. \& Andrews M. 1999. Ammonium can stimulate nitrate and nitrite reductase in the absence of nitrate in Clematis vitalba. Plant Cell Environmental Science. 22: 859-866.

Caviglia O.P. and Sardas V. 2001. Effect of nitrogen supply on crop conductance, water and radiation use efficiency of barley. Field Crops Res. 69: 259-266.

Ding, S., Oba, M., Swift, M.L., O’Donovan, J.T., Edney, M. J., McAllister, T.A., \& Yang, W.Z. 2015. In vitro gas production and dry matter digestibility of malting barley grain sown with different seeding and nitrogen fertilization rates in Canada. Animal Feed Science and Technology, 199: 146-151.

El-Awady, M. A. H. M., El-Tarras, A. A. E. S., \& El-Assal, S. E. D. 2012. Genetic diversity of some saudi barley (Hordeumvulgare L.) landraces based on two types of molecular markers. American Journal of Applied Sciences,9: 752.

Faki H, Hassan, A., Elahmadi, M. 1990. Adoption of Improved Wheat Technology in The Sudan: Survey results. ICARDA Social Paper, Allepo, Syria 5 53-55.

Fernado S. and M. Daniel. J. 2008. Radiation interception, biomass production and grain yield as affected by the interaction of nitrogen and sulfur fertilization on barley. Europ. J. of Agron. 28(3): 282-290.

Garrido-Lestache EL, L. Opez-Bellido RJ. 2005. Durum wheat quality under Mediterranean conditions as affected by nitrogen rate, timing and splitting, $\mathrm{N}$ forms and S fertilization. Europ. J. Agron. 23: 265-278.

Greenwood DJ. 1982. Modelling of crop response to nitrogen fertilizer.Philosophical Transactions of the Royal Society of London B296, 351 \pm 62 .

Gustfson A. A. 2010. Hand book of fertilizers, their source, makeup, effect and use (3rd). Agronomy bio Science, India. Pp. 77-86.

Hay RKM, Walker AJ. 1989. An introduction to the physiology of crop yield. Harlow, Essex: Longman, 174-84. Ingested T1982. Relative addition rate and external concentration driving variables used in plant nutrition research. Plant Cell and Environment 5, 443-53.physiological responses. Agron. J. 7: 632- 641.

Jaradat, A.A., \& Haddad, N.I. 1994: Analysis and Interpretation of Mashreq Project Findings (1990-92). SpecialReport: Increased Productivity of Barley, Pasture and Sheep (RAB / 98 / 026). West Asia Regional Program. ICARDA, Amman.

Panhwar F. 2004. The role of Nitrogen Fertilizer in Agriculture Digital verlag Gmbh Germany. http://www.Chemlin Com.

Randdhawa P.S. and Arora C.L. 2000. Phosphorus-sulfur interaction effect on dry matter yield and nutrient uptake by wheat. Journal of Indian society of soil science. 48(3):536- 540.

RANELLS, N.N., WAGGER, M.G.,Nitrogen release from crimson clover in relation to plant growth stage and composition,Agron.J. 84 (1992) 424-430.CAPURRO, E., et al., Yields and NPK response of barley in SW Uruguay, CIAAB Misc Pub.43 (1982) 1-21

Rizk F.A., Shaheen A.M., Abd El-Samad E.H. \& Sawan O.M. 2012. Effect of different nitrogen plus phosphorus and sulphur fertilizer levels on growth, yield and quality . Journal of Applied Science Research. 8(7):33533361.

Sinclair TR, Muchow RC 1995. Effects of nitrogen supply on maize yield, I: modeling

Steel R.G.D.and J.H. Torrie. 1997. Principles and procedures of statistics.A Biometrical Approach.McGraw Hill, New York.

Wagan M.R., F.C. Oad and K.S.Nenwani. (2003). Quantative and qualitative characteristics of barley crop under various sources and methods of nitrogenous fertilizer application. Asian J.of Plant. Sci. 2(9): 683-687. 